\title{
Terapi Bermain untuk Menurunkan Perilaku Agresi pada Anak-anak di Pesantren X, Surabaya
}

\section{Play Therapy to Reduce Aggressive Behavior in Children at Pesantren $X$, Surabaya}

\author{
Nisrina Dwi Pramara Putri ${ }^{\left(1^{*}\right)} \&$ Ika Yuniar Cahyanti( ${ }^{2)}$ \\ Fakultas Psikologi, Universitas Airlangga, Indonesia
}

Disubmit: 22 Oktober 2021; Diproses: 23 Oktober 2021; Diaccept: 12 November 2021; Dipublish: 02 Desember 2021

*Corresponding author: E-mail: nisrina.dwi.pramara-2018@psikologi.unair.ac.id

\begin{abstract}
Abstrak
Penelitian ini bertujuan untuk mengetahui perbedaan perilaku agresif pada anak-anak di Pesantren X, Surabaya sebelum dan sesudah mengikuti terapi bermain. Penelitian ini menggunakan metode kuantitatif dengan jenis penelitian eksperimen, yaitu one group pretest-posttest. Subjek penelitian ini berjumlah empat orang berdasarkan metode purposive sampling yaitu anak laki-laki, berusia antara 8-12 tahun, dikeluhkan oleh pembina asrama memiliki perilaku agresif baik fisik/verbal dan hasil pemeriksaan CBCL memiliki tingkat perilaku agresi pada kategori di area garis ambang atau di atas garis ambang. Alat ukur yang digunakan dalam penelitian ini adalah kuesioner perilaku agresi yang dikembangkan oleh Medinus dan Johnson (1976, dalam Kristianto, (2009) yang telah diadaptasi di Indonesia oleh Kristianto, (2009) dengan estimasi reliabilitas alpha cronbach sebesar 0,940. Hasil penelitian dianalisis dengan teknik uji-t paired sample test melalui aplikasi SPSS 21 for windows. Hasil analisis data yang telah dilakukan pada penelitian ini menunjukkan bahwa terdapat perbedaan yang signifikan antara mean skor perilaku agresi pada pretest dan posttest sebesar 0.002 (sig. $<0.05$ ) setelah pemberian terapi bermain pada anak-anak di Pesantren X, Surabaya. Hasil penelitian tersebut menunjukkan bahwa terapi bermain dapat menurunkan perilaku agresi pada anak-anak.
\end{abstract}

Kata Kunci: Anak-anak; Perilaku Agresi; Terapi Bermain

\begin{abstract}
This study aims to determine differences in aggressive behavior in children at Pesantren X, Surabaya before and after participating in play therapy. This study uses a quantitative method with the type of experimental research, namely one group pretest-posttest. The subjects of this study amounted to four people based on purposive sampling method, namely boys, aged between 8-12 years, complained by the hostel builder that they had aggressive behavior both physically/verbally and the results of the CBCL examination had a level of aggressive behavior in the categories in the threshold area or in the above the threshold. The measuring instrument used in this study is the aggression behavior questionnaire developed by Medinus and Johnson (1976, in Kristianto, (2009) which has been adapted in Indonesia by Kristianto, (2009) with an estimated Cronbach alpha reliability of 0.940. The results of the study were analyzed by using the paired sample test $t$-test technique through the SPSS 21 for windows application. The results of data analysis that have been carried out in this study indicate that there is a significant difference between the mean scores of aggressive behavior on the pretest and posttest of 0.002 (sig. $<0.05)$ after giving play therapy to children at Pesantren $X$, Surabaya. The results of this study indicate that play therapy can reduce aggressive behavior in children.
\end{abstract}

Keywords: Children; Aggressive Behavior; Play Therapy

DOI: https://doi.org/10.51849/j-p3k.v2i3.121

\section{Rekomendasi mensitasi :}

Putri, N.D.P. \& Cahyanti, I.Y. (2021). Terapi Bermain untuk Menurunkan Perilaku Agresi pada Anak-anak di Pesantren X, Surabaya. Jurnal Penelitian Pendidikan, Psikologi dan Kesehatan (J-P3K), 2 (3): 259-267. 


\section{PENDAHULUAN}

Setiap anak adalah seorang pribadi unik yang memiliki pola perilaku dan perkembangan yang bersifat individual. Anak-anak usia sekolah dasar pada umumnya berada dalam proses perkembangan yang berlangsung dengan cepat baik dalam aspek fisik, emosional, intelektual dan sosial. Dalam setiap tahap perkembangan yang dialami tersebut, tak jarang anak melakukan perilaku yang tidak sesuai dengan norma. Perilaku yang tidak sesuai dengan norma-norma yang ada di masyarakat pada umumnya dimaknai sebagai kenakalan pada anak. Kenakanalan merupakan produk konstitusi defektif dari mental dan emosi anak yang belum matang (labil) dan rusak (defektif) sebagai akibat proses pengkondisian oleh lingkungan yang tidak bersahabat (Kartono, 2007).

Pesantren X adalah program pemberdayaan anak-anak yatim dan fakir miskin dengan sistem Asrama (total education). Konsep asrama pada program Pesantren X ini memungkinkan anak-anak santri yatim dan fakir miskin memperoleh pembinaan kecerdasan terpadu (multiple intelegence), yaitu dalam segi agama (SQ), intelektualitas (IQ), dan sikap (EQ). Setiap individu santri mendapatkan fasilitas pembelajaran yang dapat meningkatkan kompetensi mereka di masa yang akan datang secara gratis.

Jumlah anak-anak santri yang terdapat di Pesantren X saat ini berjumlah 19 orang, dengan rentang usia 7-13 tahun. Anak-anak santri yang tinggal di asrama berasal dari berbagai latar belakang keluarga yang berbeda-beda. Mayoritas, anak-anak santri yang tinggal di asrama karena orang tua yang menyerahkan anaknya dikarenakan orang tua sudah tidak sanggup untuk memenuhi kebutuhan dasar anak. Latar belakang kesulitan hidup yang dirasakan oleh anakanak tersebut memiliki dampak beraneka ragam dalam diri mereka, salah satunya adalah munculnya perilaku agresi.

Berdasarkan hasil pengamatan dan wawancara dengan pembina asrama di Pesantren $\mathrm{X}$, anak-anak yang tinggal di asrama seringkali melakukan perilaku agresi. Menurut pembina asrama, perilaku agresi tersebut dilakukan ketika anakanak ingin melindungi diri mereka karena gangguan dari teman-teman lainnya atau ketika mereka menginginkan sesuatu namun tidak mengetahui bagaimana cara yang lebih baik untuk meraihnya. Hal ini ditunjukan dengan perilaku mudah marah dan apabila mereka sedang marah biasanya mereka mengungkapkan kemarahan tersebut dengan perilaku agresi baik yang berbentuk fisik maupun yang berbentuk verbal.

Perilaku agresi secara fisik yang seringkali mereka lakukan seperti memukul, menendang, mendorong, merampas, dan mencubit orang lain yang menyebabkan luka fisik. Sedangkan perilaku agresi secara verbal yang dilakukan anak seperti berkata-kata kasar, mengejek, membentak, membantah dan mengancam orang lain yang menyebabkan perasaan sakit hati.

Perilaku agresi secara psikologis adalah perilaku menyerang sesuatu yang dipandang sebagai hal yang mengecewakan, menghalangi atau menghambat. Pada masa perkembangan anak, perilaku ini muncul karena pada masa ini anak sudah mulai merasa ingin mengetahui dan ingin melakukan sesuatu 
yang dia inginkan walaupun tanpa dia sadari sesuatu yang dia lakukan itu dapat berdampak negatif pada dirinya ataupun orang lain (Hurlock, 1987 dalam Stevani, 2018).

Perilaku agresi sesungguhnya merupakan reaksi normal pada anak-anak yang masih kecil. Anak-anak secara naluriah menghadapi perilaku ini ketika mereka merasa tidak nyaman, ketika mereka ingin melindungi diri mereka sendiri, atau ketika mereka ingin mencapai tujuan tertentu tetapi tidak tahu bagaimana mencapainya dengan lebih baik

Selain itu, perilaku agresif juga merupakan cara khas anak kecil untuk menunjukkan kepada orang lain bahwa mereka tidak suka pada apa yang dilakukan orang lain terhadap mereka, akan tetapi seiring dengan bertambahnya usia mereka, anak-anak seharusnya menjadi semakin mampu menggunakan cara-cara yang lebih tepat untuk meraih tujuannya, sehingga tidak perlu bertindak dengan cara yang agresif.

Perilaku agresif menjadi bagian dari tahapan perkembangan mereka dan sering kali menimbulkan masalah, baik itu di rumah, sekolah ataupun dalam suatu lingkungan masyarakat yang mana disuatu tempat tersebut dia dapat berinteraksi terutama dengan orang lain. Setelah melewati usia 7 tahun, anak diharapkan sudah lebih dapat mengendalikan dirinya untuk tidak menyelesaikan masalah dengan perilaku agresif (Zahara et al., 2018).

Secara umum terdapat dua aspek yang dapat digunakan untuk memahami perilaku agresi, yaitu (1) Agresi fisik merupakan kecenderungan anak melakukan serangan fisik sebagai ungkapan ekspresi kemarahan seperti memukul, menggigit, mencubit, menendang, menginjak, melempar barang ke orang, dan sebagainya. (2) Agresi verbal yaitu kecenderungan untuk menyerang orang lain secara verbal seperti dengan mengucapkan kata-kata yang menghina atau mengejek, mengumpat dengan kata-kata kasar, melecehkan, mengintimidasi, membentak orang yang lebih tua, atau memberi perintah sewenang-wenangnya kepada orang lain (Buss dan Perry, 1992 dalam Zahara et al., 2018).

Lindwood (2006) mengatakan bahwa agresi pada anak berhubungan dengan keluarga yang berasal dari status ekonomi menengah ke bawah, kriminalitas, atau adanya gangguan psikologis. Selain itu, Wirawan (2009) menambahkan bahwa perilaku agresif disebabkana adanya masalah lingkungan, individual, situasional, media massa, dan adanya kekerasan dalam rumah tangga. Selain itu, anak yang sering melihat dan menyaksikan kekerasan dalam rumah tangga baik secara langsung atau tidak langsung yang dilakukan ayah terhadap ibu dan anaknya dapat membentuk perilaku agresi pada anak.

Menurut Lansford (dalam Ekasetiawati, 2017) perilaku agresi yang dilakukan dalam jangka waktu yang panjang akan berdampak pada perkembangan kepribadian seseorang, yaitu menjadi pemarah, sensitifitas yang tinggi, kurangnya penerimaan sosial, kurangnya self control, kecemasan, penyimpangan perilaku seperti anti sosial dan psikopat. Selain itu Jhung (2016) menjelaskan bahwa perilaku agresi pada anak sekolah 
dasar dapat menyebabkan psikopatologi dan internalisasi peirlaku, sehingga dapat terjadinya keluhan somatik, kecemasan, depresi, masalah sosial, masalah kognitif, masalah perhatian, pelanggaran aturan, serta bullying dan memungkinkan korban agresivitas juga melakukan perilaku agresi pada orang lain sebagai pelampiasan emosinya.

Mengingat betapa besarnya dampak masalah psikologis dari perilaku agresi, maka perilaku agresi membutuhkan penanganan melalui proses terapi, salah satunya adalah terapi bermain (play therapy). Menurut Landreth (dalam Mashar, 2015) terapi bermain adalah hubungan yang dinamis antara anak (atau orang dari segala usia) dan terapis yang terlatih dalam prosedur terapi bermain yang menyediakan bahan yang dipilih untuk bermain dan memfasilitasi pengembangan hubungan yang aman untuk anak sepenuhnya mengekspresikan dan mengekplorasikan diri (perasaan, pikiran, pengalaman, dan perilaku) anak dapat berkomunikasi secara optimal serta mengungkapkan kesulitan-kesulitan yang dirasakan membuat anak akan menjadi lebih nyaman karena berada dalam situasi yang menurutnya menyenangkan.

Terapi bermain berfungsi sebagai perkembangan sensori, sosial, bahasa, fisik-motorik, moral, kesadaran diri, kreatifitas dan juga nilai teraupetik (Supartini, dalam Ekasetiawati, 2017). Penelitian lain juga mengungkapkan bahwa terapi bermain memiliki dampak yang positif dalam menurunkan tingkat agresivitas pada anak secara perorangan maupun kelompok. Penelitian yang dilakukan oleh Chotim, dkk., (2016) mengungkapkan bahwa terapi bermain dalam bentuk ular tangga dan drama boneka dapat membantu mengurangi tingkat agresivitas anak usia TK.

Selain itu, Jarareh, dkk., (2016) melalui penelitiannya mengungkapkan bahwa dari 60 siswa prasekolah yang terdiri dari 30 subjek kelompok eksperimen dan 30 subjek kelompok kontrol diketahui bahwa terapi bermain berkelompok untuk anak prasekolah dapat meningkatkan kreativitas dan mengurangi agresi pada anak-anak prasekolah. Diana (2007) melalui penelitiannya juga mengungkapkan bahwa dari kedua kelompok yaitu, kelompok kontrol dan eksperimen diketahui bahwa kelompok eksperimen mengalami perbedaan saat diberikan perlakuan terapi bermain secara berkelompok, sehingga mampu menurunkan kecenderungan perilaku agresif pada anak.

Oleh karena itu, berdasarkan dari pemaparan di atas peneliti ingin melaksanakan proses intervensi kelompok dengan pendekatan terapi bermain untuk menurukan perilaku agresi pada kelompok anak yang memiliki perilaku agresi.

Jenis terapi bermain yang akan diterapkan dalam bentuk permainan ular tangga dan dilakukan mengikuti peraturan yang sudah ada dengan modifikasi pemberian kartu-kartu berisi peraturan pertanyaan serta tantangan yang diberikan untuk memberikan pemahaman serta pembelajaran pada anak. Terapi bermain juga dilakukan dengan memberikan reward dan punishment sebagai reinforcement atau penguatan perilaku agar anak dapat mengurangi perilaku agresifnya. 
Tujuan penelitian ini adalah untuk mengetahui efektivitas terapi bermain untuk mengurangi perilaku agresi pada anak-anak di Pesantren X, Surabaya.

\section{METODE PENELITIAN}

Penelitian ini menggunakan pendekatan kuantitatif dengan jenis penelitian eksperimen, yaitu one group pretest-posttest. Metode ini menggunakan satu kelompok yang diberikan alat ukur sebelum dan setelah diberikannya intervensi. Alat ukur yang digunakan dalam penelitian ini adalah kuesioner perilaku agresi yang dikembangkan oleh Medinus dan Johnson (1976, dalam Kristianto, 2009) yang telah diadaptasi di Indonesia oleh Kristianto (2012). Adapun hasil estimasi reliabilitas alat ukur ini berdasarkan alpha cronbach adalah sebesar 0,940 .

Teknik sampling yang digunakan dalam penelitian ini adalah purposive sampling, yaitu peneliti menetapkan kriteria sampel atau responden seperti berjenis kelamin laki-laki, berusia 8-12 tahun, dikeluhkan oleh pembina asrama terkait perilaku agresi baik fisik/verbal dan hasil pemeriksaan CBCL memiliki tingkat perilaku agresi pada kategori di area garis ambang atau di atas garis ambang. Penelitian ini melibatkan 4 orang anak laki-laki. Penelitian dilakukan dalam enam kali pertemuan.

Teknik analisa data yang digunakan dalam penelitian ini menggunakan uji-t paired sample test untuk mengetahui perbedaan kondisi perilaku agresi yang dilakukan oleh anak-anak sebelum dan setelah diberikannya intervensi.

\section{HASIL DAN PEMBAHASAN}

Peneliti mengolah data pretest dan posstest menggunakan SPSS statistic version 21 for windows dengan uji-t paired sample test dengan tujuan untuk mengetahui perbedaan mean skor pengetahuan sebelum dan setelah mengikuti intervensi. Teknik statistik yang digunakan adalah statistik non parametrik dengan uji-t yang digunakan untuk data yang tidak berdistribusi normal. Hipotesis pengujian yang dilakukan, yaitu:

H0: Tidak terdapat perbedaan mean skor perilaku agresi responden penelitian sebelum dan sesudah mengikuti terapi bermain.

Ha: Terdapat perbedaan mean skor perilaku agresi responden penelitian sebelum dan sesudah mengikuti terapi bermain.

Tabel 1 Hasil Uji-T Pired Sample Statistics

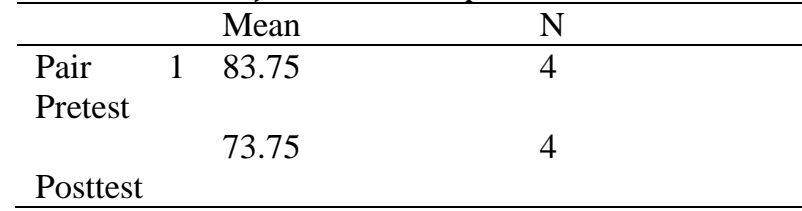

Berdasarkan tabel di atas diketahui bahwa bahwa hasil uji paired samples statistics terhadap keempat anggota kelompok, diperoleh nilai rata-rata pretest sebesar 83,75, sedangkan untuk nilai posttest diperoleh nilai rata-rata sebesar 73,75. Hal ini menunjukkan adanya perbedaan nilai pretest dan posttest pada anggota kelompok, dimana adanya penurunan nilai rata-rata dari pengisian pretest dan posttest.

\begin{tabular}{|c|c|c|c|}
\hline \multicolumn{4}{|c|}{ Paired Differences } \\
\hline & & Mean & Sig. (2-tailed) \\
\hline $\begin{array}{l}\text { Paired } \\
\text { Pretest- } \\
\text { Posttest }\end{array}$ & & & .002 \\
\hline
\end{tabular}


Tabel uji-T Pired Sample Test menunjukkan nilai Sig. (2-tailed) $=0,002$ lebih kecil dari nilai Sig. (2-tailed) $<0,05$. Hal tersebut berarti bahwa Ho ditolak dan Ha diterima yang memiliki arti bahwa, terdapat perbedaan mean skor perilaku agresi responden penelitian sebelum dan sesudah mengikuti terapi bermain.

Kegiatan intervensi kelompok ini dilakukan berdasarkan keluhan dan analisis situasi yang terjadi di lapangan. Secara umum beberapa anak yang tinggal di asrama Pesantren $X$ ini memiliki kecenderungan perilaku agresif yang dikeluhkan oleh pembina asrama. Bentuk dari perilaku agresif yang dilakukan oleh anak beraneka ragam baik perilaku agresif secara fisik maupun perilaku agresif secara verbal.

Perilaku agresi secara fisik yang dilakukan anak dan dikeluhkan seperti memukul, menendang, dan mencubit. Hal tersebut sesuai dengan yang diungkapkan oleh Medinus dan Johnson (dalam Kristianto, 2009) bahwa agresi fisik (physical aggression) dapat melukai, mengganggu, atau membahayakan orang lain melalui respons motorik dalam bentuk fisik, seperti memukul, menendang, mendorong, meludahi menggigit, mencubit, dan lain sebagainya.

Sedangkan perilaku agresi secara verbal yang dilakukan anak dan dikeluhkan seperti berkata-kata kasar, mengejek, dan mengancam orang lain. Hal tersebut sesuai dengan pernyataan kembali dari Medinus dan Johnson (dalam Kristianto, 2009) yang mengatakan bahwa agresi verbal (verbal aggression) adalah tindakan agresi yang bertujuan untuk menyakiti, mengganggu, atau membahayakan orang lain dalam bentuk penolakan dan ancaman melalui respon vokal dalam bentuk verbal seperti seperti mengancam, mengejek, membentak, menuntut secara verbal, dan lain sebagainya.

Pembentukan kelompok terjadi atas dasar karakteristik yang sama dimiliki setiap subjek yaitu memiliki keluhan terkait perilaku agresi baik secara fisik maupun verbal, berusia antara 8-12 tahun serta memiliki tingkat agresivitas yang berada pada kategori di area garis ambang atau di atas garis ambang berdasarkan pengukuran aspek aggresivitas CBCL. Anak-anak yang memiliki kriteria tersebut kemudian dikelompokkan melakukan proses intervensi kelompok berbentuk terapi bermain yang bertujuan untuk menurunkan perilaku agresi, sehingga anak-anak tersebut dapat menampilkan perilaku yang lebih positif dalam kehidupan sehari-hari.

Proses terapi bermain secara umum memiliki unsur perkembangan sosial dan juga moral yang dijelaskan oleh Supartini (2014), perilaku agresi merupakan salah satu permasalahan sosial karena rendahnya moral yang dapat membuat perkembangan sosial terhambat dan juga menyimbang. Terapi bermain pun diberikan karena aktivitas bermain merupakan dunia anak yang sepanjang masa perkembangannya dan melibatkan interaksi sosial yang mendekati fenomena kehidupan sosial yang nyata.

Menurut Harpine (2008), terapi bermain yang diterapkan dalam kelompok akan memberi proses terapuitik dan menimbulkan motivasi intrinsik bagi anak, sehingga anak dapat tumbuh, belajar dan berubah dalam lingkungan positif. Dengan bermain anak akan belajar untuk 
mengamati apa yang dimainkan, apa yang dilakukan serta anak juga akan belajar untuk berkompetensi secara sehat. Permainan edukatif tidka hanya memberikan kesenangan kepada anak sebagaimana dengan fungsi bermain secara umum, namun juga memberikan pemahaman dan pembelajaran yang baik bagi anak agar dapat mengaplikasikannya kedalam kehidupan sehari-hari.

Proses intervensi terapi bermain yang diberikan kepada anggota kelompok menggunakan media ular tangga tidak hanya memberikan kesenangan bagi anggota kelompok, namun juga memberikan wadah kepada anak untuk mengeluarkan emosi-emosi negatif yang dirasakan oleh anak sebagai katarsis agar anak merasa nyaman mengeluarkan pendapat serta dapat belajar dari pengalaman-pengalaman mereka sebelumnya, sehingga dapat merubah perilaku mereka menjadi lebih positif untuk perkembangan psikososial mereka.

Sebelum memulai intervensi para anggota kelompok sepakat untuk menerapkan peraturan yang ditetapkan selama berlangsungnya terapi bermain. Peraturan-peraturan tersebut antara lain: berkata dengan sopan dan santun, tidak mencela ketika ada orang yang sedang berbicara, tidak berbuat kasar baik fisik maupun verbal dan mengikuti rangkaian permainan hingga selesai. Peraturanperaturan tersebut membuat setiap anggota kelompok belajar mengetahui perilaku mana yang baik dan tidak baik serta perilaku mana yang dapat dilakukan dan mana yang tidak dapat dilakukan.

Selama berlangsungnya intervensi setiap anggota kelompok pun saling mengingatkan jika ada anggota kelompok yang melanggar peraturan, seperti $\mathrm{F}$ yang mengingatkan $G$ agar berkata yang sopan saat $G$ mengumpat kepada $B$, begitu juga $R$ yang mengingatkan $B$ untuk menunggu giliran mengocok dadu. Selain itu, setiap anggota kelompok juga belajar dari setiap pertanyaan, tantangan serta feedback yang berkaitan langsung dengan aspek perilaku agresif, seperti subjek B dan R yang berani meminta maaf kepada temannya karena telah pernah melakukan perilaku yang salah. Sedangkan pada saat proses feedback, setiap anggota kelompok dilatih untuk memilah informasi dan memutuskan apa yang harus dilakukan melalui pengalaman-pengalaman untuk diaplikasikan pada kehidupannya seharihari.

Adanya reward dan punishment sebagai penguatan perilaku (reinforcement) juga memotivasi anggota kelompok untuk tetap melakukan perilaku baru yang diinginkan. Reward diberikan ketika anggota kelompok dapat menjawab pertanyaan, menyelesaikan tantangan atau permainan, begitu juga sebaliknya punishment diberikaan saat anggota kelompok tidak dapat menjawab pertanyaan atau menyelesaikan tantangan. Hal tersebut terbukti dapat meningkatkan motivasi setiap anggota kelompok yang diketahui dari keempat anggota kelompok antusias untuk menyelesaikan permainan dan berusaha menjawab setiap pertanyaan atau menyelesaikan tantangan yang mereka dapatkan.

Hasil dari skor pengukuran pretest dan posttest yang dilakukan juga menunjukkan penurunan skor dari setiap anggota kelompok. Hal tersebut menunjukkan bahwa terapi bermain dengan media ular tangga merupakan 
bentuk perlakuan yang dapat menurunkan perilaku agresif setiap anggota kelompok. Sejalan dengan penelitian yang dilakukan oleh Ekasetiawati, (2017) yang mengatakan bahwa terapi bermain dapat digunakan untuk menurunkan agresivitas pada anak.

Berdasarkan hasil evaluasi yang telah dilakukan oleh pemeriksa dengan melakukan wawancara kepada pembina asrama di Pesantren $\mathrm{X}$ setelah dilakukannya intervensi diketahui bahwa para peserta memahami perilaku agresi yang mereka lakukan baik yang berbentuk fisik maupun verbal merupakan perilaku yang salah. Para peserta saat ini cukup dapat mengontrol rasa marah yang mereka miliki, meskipun hal tersebut belum secara konsisten mereka lakukan. Mereka sesekali masih memunculkan perilaku agresi berbentuk fisik maupun verbal, namun hanya dalam situasi tertentu dan ketika dingatkan mereka sudah mau mendengarkan.

\section{SIMPULAN}

Hasil penelitian menunjukkan bahwa terapi bermain dapat menurunkan mean skor perilaku agresif pada anak-anak. Hal ini dikarenakan anggota kelompok memahami bagaimana perilaku agresi dan dampaknya bagi diri sendiri maupun orang lain. Anggota kelompok berusaha untuk mengontrol dirinya agar tidak berperilaku agresi, meskipun terkadang mereka masih merasa sulit untuk mengendalikan emosinya agar tidak berperilaku agresi.

\section{DAFTAR PUSTAKA}

Chotim, M., Dian, R., Noviyanti, K. (2016). Mengurangi Tingkat Agresivitas Anak Usia TK melalui Terapi Bermain (Play Therapy). Jurnal Bimbingan dan Konseling, 1(1), 1-13.
Diana, M. (2007). Terapi Bermain Kelompok untuk Mengurangi Kecenderungan Perilaku Agresif pada Anak. Doctocal Dissertation. Jurnal Universitas Muhamadiyah Malang.

Ekasetiawati, D. N. (2017). Play Therapy untuk Mengurangi Agresivitas pada Anak LakiLaki Usia Sekolah Dasar. Skripsi. Fakultas Psikologi, Universitas Muhamadiyah Malang.

Jarareh, J., Aref, M., Maghsoud, N. (2016). The Impact of Group Play Therapy on Creativity and Control of Aggression in Preschool Children. Cogent Psychology, 3(1), 1-9.

Kartono, K. (2007). Perkembangan psikologi anak. Jakarta: Erlangga.

Kristianto, A. (2009). Perilaku Agresif Anak-Anak Perkampungan Sosial Pingit Yayasan Sosial Soegijapranata. Skripsi. Fakultas Psikologi, Universitas Sanata Dharma.

Hanan, F., Debora, D., Santy, Y. (2018) Penerapan Group Arth Therapy Bagi Anak-Anak Masa Pertengahan yang Memiliki Kecenderungan Agresi Verbal. Jurnal Muara Ilmu Sosial, Humaniora, dan Seni, 2(1), 97-107.

Harpine, E.C. (2008). Group Interventions Inschools, Promoting Mental Health For Risk Children and Youth. New York: Springer

Hartini, I. (2009). Agresi Anak yang Tinggal dalam Keluarga dengan Kekerasan Rumah Tangga. Skripsi. Fakultas Psikologi, Universitas Gunadarma.

Indriyani, I. (2011) Play Therapy: Pemebelajaran Mitigasi Bencana Tanah Longsor untuk ABK. Bulletin Vulkanologi dan Bencana Geologi, 6(3), 7-15.

Mashar, R., (2005). Play Therapy dalam Kelompok Guna Meningkatkan Emosi Positif Anak Usia Dini. Jurnal Universitas Muhamadiyah Malang.

Nawangsih, E. (2017). Play Therapy untuk AnakAnak Korban Bencana Alam yang Mengalami PTSD. Psympathic, Jurnal Ilmiah Psikologi, 1(2), 164-178.

Rangkuti, A. A., (2017). Konsep dan Teknik Analisis Data Penelitian Kuantititaif Bidang Psikologi dan Peniddikan. Jakarta: FIP Press.

Santrock, J. W. (2012) Life Span Development Jilid 1. Jakarta: Erlangga.

Stevani, Debora, D., Florencia, I. (2018). Penerapan Assertive Behavior Therapy untuk Menurunkan Perilaku Agresi Verbal pada Anak Di Lembaga X. Jurnal Muara Ilmu Sosial, Humaniora, dan Seni, 2(1), 205-214.

Sugiyono. (2013). Metode Penelitian Kuantittaif, Kualitatif dan R\&D. Bandung: Alfabeta, CV.

Supartini, Y. (2014). Buku Ajar Konsep Dasar Keperawatan Anak. Jakarta: EGC. 
Sweeney, D., Baggerly, J., Ray, D. (2014). Group Play Therapy: A Dynamic Approach. New York: Routledge,

https://doi.org/10.4324/9780203103944

Walsh, J. (2010). Psychoeducation In Mental Health. Chicago: Lyceum Books, Inc.

Wirawan. (2009). Evaluasi Kinerja Sumber Daya Manusia: Teori Aplikasi dan Penelitian. Jakarta: Salemba Empat.

Zellawati, A. (2011). Terapi Bermain untuk Mengatasi Permasalahan pada Anak. Majalah Ilmiah Informatika, 2(3), 164-175. 